\title{
Characterization of soft-bottom benthic habitats of the Åland Islands, northern Baltic Sea
}

\author{
E. Bonsdorff ${ }^{1, *}$, R. J. Diaz ${ }^{2}$, R. Rosenberg ${ }^{3}$, A. Norkko ${ }^{1}$, G. R. Cutter $\mathrm{Jr}^{2}$ \\ ${ }^{1}$ Husö Biological Station, Department of Biology, Åbo Akademi University, FIN-22220 Emkarby, Åland, Finland \\ ${ }^{2}$ The College of William \& Mary, School of Marine Science, Virginia Institute of Marine Science, Gloucester Point, \\ Virginia 23062, USA \\ ${ }^{3}$ Kristineberg Marine Research Station, Göteborg University, S-450 34 Fiskebäckskil, Sweden
}

\begin{abstract}
Sediment surface and profile imaging (SPI) was used in combination with grab sampling of sediment (sediment type, organic content, benthic infauna) and hydrography (temperature, oxygen saturation of bottom water) to analyze and describe the soft-bottom benthic habitats of the Aland archipelago $\left(60^{\circ} 00^{\prime}\right.$ to $60^{\circ} 30^{\prime} \mathrm{N}, 19^{\circ} 30^{\prime}$ to $\left.20^{\circ} 30^{\prime} \mathrm{E}\right)$ in the northern Baltic Sea. The SPI analysis covered 42 stations ( 5 to $263 \mathrm{~m}$ depth), from inner sheltered bays to open coastal waters, with varying sediment types (soft mud with high organic content to sandy substrates with low organic content; loss on ignition: 0.5 to $12.4 \%$ ). Clustering of the sampled stations (sediment properties) yielded 3 distinct categories of sedimentary habitats: (1) inner archipelago areas and bays with high organic content of the sediment and reduced oxygen saturation in the bottom water, (2) archipelago waters with intermediate values of all analyzed parameters, and (3) open coastal sediments with low organic content and high oxygen saturation (2 deep of fshore stations formed an additional group based primarily on depth). Visual analysis of the images provided information on several additional abiotic and biotic characteristics of the sediment, and significant correlations were found mainly between oxygen saturation, organic content, sediment type, shear strength (penetration of gear), surface relief and the depth of the redox potential discontinuity layer in the sediment. The sediment properties were also reflected in the zoobenthos. The correlations between parameters measured are discussed in relation to applicability of the SPI method, monitoring demands, and basic understanding of the sediment-animal relationships.
\end{abstract}

KEY WORDS: Sediment profile imaging $\cdot$ Benthic habitats $\cdot$ Zoobenthos $\cdot$ Hydrography $\cdot$ Baltic Sea

\section{INTRODUCTION}

Benthic studies have traditionally involved a visual description of the sediment (sediment type, colour, smell, etc.) in relation to the infaunal assemblages recorded. In order to explain functional aspects of the biota, the need for a more detailed analysis and understanding of both the pelagic and the sedimentary environments is obvious (Graf 1992, Snelgrove \& Butman 1994 , and references in them). Thus, the perception of benthic ecology has become more complex, gradually involving more sophisticated field methods. Further, the need for rapid and accurate measurements and subsequent classification of the benthic environment

\footnotetext{
·E-mail: erik.bonsdorff@abo.fi
}

has evolved with increasing environmental problems and demands for impact studies. To meet some of these demands, various methods of sediment photography have been developed, leading to the present sediment profile imaging techniques used both in monitoring and basic research, enabling in situ characterization of sediment habitats including the fauna (Rhoads \& Cande 1971, Rhoads \& Germano 1982, 1986, O'Connor et al. 1989, Diaz \& Gapcynski 1991, Grizzle \& Penniman 1991, Grehan et al. 1992, Rumohr \& Schomann 1992, Rumohr et al. 1992, Valente et al. 1992, Diaz et al. 1993).

Large areas of the open Baltic Sea are in a more or less persistent anoxic state. When infauna is present in adjacent hypoxic areas, diversity is low and most individuals are small (Andersin \& Sandler 1989, 1991). 
Niemistö \& Winterhalter (1977) provided the first attempt in the northern Baltic Sea to study the sediment surface oxygen conditions by sediment photography. Rumohr et al. (1992), Schaffner et al. (1992), Rosenberg \& Diaz (1993) and Rumohr (1993) were the first to use sediment profile imaging to analyze both the sediment and the biota in Baltic waters.

The objective in the present study was to classify the benthic environments in the Aland archipelago (Fig. 1). The aims of this study were to (1) characterize the sediment and zoobenthic habitats in the Aland archipelago, (2) describe qualitatively and quantitatively the benthic infauna, (3) test for connections between hydrographic features, sediment quality and zoobenthos, and (4) discuss the relevance of sediment surface and profile imaging (SPI) in the low-saline, species-poor Baltic Sea in relation to other sea areas. The results from this study are compared with quantitative sampling of zoobenthos that was carried out at 25 of the 42 stations studied during June and July 1992-1994 (Norkko \& Bonsdorff 1994, Bonsdorff et al. 1997). Zoobenthic communities of the $\AA$ land area are already well documented (Westerberg 1978, Bonsdorff et al. 1991, 1992, 1997, Bonsdorff \& Blomqvist 1993, Norkko \& Bonsdorff 1994). The northern Baltic coasts and archipelago are influenced by eutrophication
(Cederwall \& Elmgren 1990, Bonsdorff et al. 1991, 1992, 1997, HELCOM 1993, Jumppanen \& Mattila 1994) which leads to periodic and seasonal hypoxia in some areas. This seems to be due to large-scale eutrophication and impact by fish-farms and agriculture rather than local point sources. The energy transfers in the system are basically known (Elmgren 1984. Leppäkoski \& Bonsdorff 1989), as are the geology and the general distribution of sediment types (Tulkki 1977, Voipio 1981, Jonsson et al. 1990, Leivuori \& Niemistö 1993, Jonsson \& Carman 1994)

\section{MATERIAL AND METHODS}

Study area. The investigated area (Fig. 1) was the extensive Åland archipelago, SW coast of Finland, northern Baltic Sea $\left(60^{\circ} 00^{\prime}\right.$ to $60^{\circ} 30^{\prime} \mathrm{N}, 1^{\circ} 30^{\prime}$ to $20^{\circ} 30^{\prime}$ E), covering approximately $7000 \mathrm{~km}^{2}$ The area is characterized by about 6500 islands, forming a mosaic of more or less distinct zonation ranging from the innermost sheltered bays to the open coastal areas. Average water depth is 20 to $25 \mathrm{~m}$, with a shoreline of over $8000 \mathrm{~km}$, emphasizing the importance of littoral, nearshore, shallow areas for the functioning of the ecosystem (Bonsdorff \& Blomqvist 1993). The sea is non-tidal,

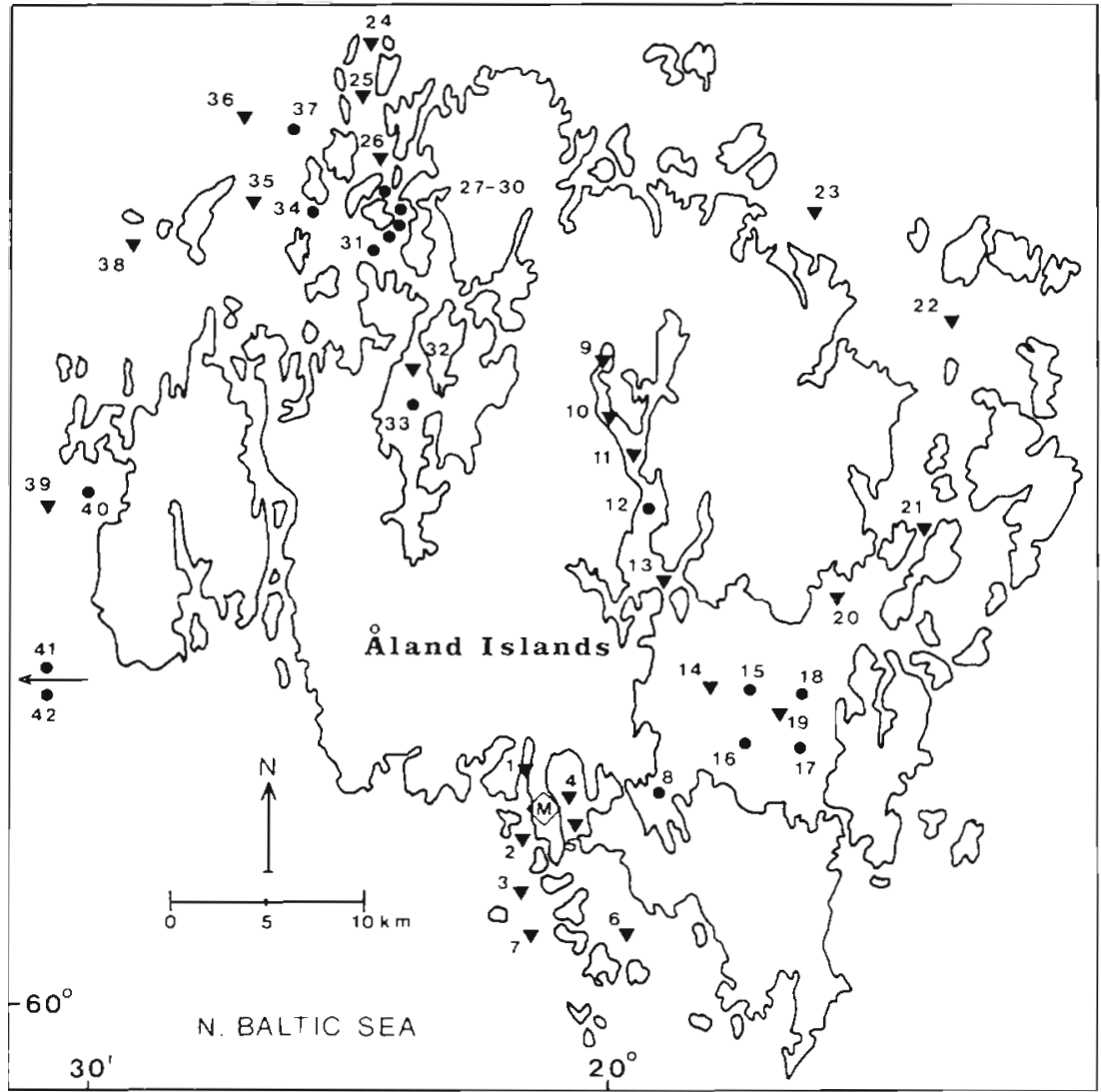

Fig. 1. Study area in the Aland archipelago, northern Baltic Sea. (•) SPI hydrography and qualitative zoobenthos; (v) SPI and quantitative zoobenthos (Norkko \& Bonsdorff 1994, Bonsdorff et al. 1992, 1997). Sediment habitats were divicled into 4 groups: Group I, inner areas, soft mud, Stns 5 , $8,9,12,28-30,32$; Group II, archipelago, Stns $1-4,6,10,11,13-20,25-27$. 31, 33; Group III, open coastal zone, Stns 7. 21-24, 34-40; Group 4, open sea, Stns 41,42 (position outside map indicated by arrow). M: Mariehamn 
but characterized by a strong seasonality, including high summer temperatures (surface waters reach 18 to $20^{\circ} \mathrm{C}$ ), and a more than $90 \%$ probability of annual ice cover during winter (Leppäkoski \& Bonsdorff 1989). Further, the land uplift after the last glaciation still prevails at 50 to $60 \mathrm{~cm}$ per $100 \mathrm{yr}$ in the $\AA$ land Islands, continuously forming new littoral areas. Due to the relatively high degree of isolation from the fully marine environment and as a consequence of the large riverine input of freshwater (Carlsson \& Bergström 1993. Pitkänen 1994), the northern Baltic Sea of today is characterized by low salinities (4 to $8 \%$ S). Regular anoxic conditions occur in the bottom waters in the open sea (Andersin \& Sandler 1989, 1991). In the archipelago areas, however, stratification due to rapid warming of the surface waters occurs annually. Generally, the Baltic Sea ecosystems are governed by prevailing latitudinal (horizontal: N-S, E-W) and vertical (depth: topography, stratification) gradients in the sea (Leppäkoski \& Bonsdorff 1989).

Field methods. In all, 42 stations (Fig. 1, Table 1) in the Aland archipelago and the adjacent Aland Sea were visited during 1 week in June 1993, and at each station (at Stns 41 and 42 SPI only; Table 1) the following sampling procedure was carried out: basic hydrography (temperature, salinity, oxygen saturation of the bottom water $50 \mathrm{~cm}$ above the sediment surface), zoobenthos (1 Ekman-Birge grab sample sieved on a $1 \mathrm{~mm}$ sieve and immediately analyzed to record dominant infauna), sediment for analysis of organic content (\% ignition loss), and sediment surface and profile imaging. The present study utilized the camera and analytical methodology described in Diaz \& Gapcynski (1991) and Rosenberg \& Diaz (1993).

Sediment profile photographs were obtained from all 42 stations (Table 1, 5 to $263 \mathrm{~m}$ depth). Stns 28, 29 and 30 were in the vicinity of a fish farm, all others were located off local point source disturbance. The camera pod contains a surface camera (photographing approximately $1 \mathrm{~m}^{2}$ of the bottom before the pod arrives at the bottom), a sediment profile camera with a $12 \times 22 \mathrm{~cm}$ prism, and an oxygen probe (YSI Environmental Monitoring Systems) for measurements of oxygen content of the near-bottom water. Agfa Chrome CT100 slide film was used in both cameras. Three replicate deployments of the camera pod were made at each station. During each deployment, 1 photograph was taken of the sediment surface to identify objects at the sediment surface, and 3 successive pictures were taken at 2 s intervals as the prism penetrated into the sediment (for details of camera and camera pod, as well as sampling procedure, see Rosenberg \& Diaz 1993).

Laboratory methods. Surface and sediment profile images were stored digitally in Kodak Photo CD for- mat. Visual and computerized analysis of the images was done using Adobe Photoshop 2.5 and NIH Image 1.52 on an Apple Macintosh Quadra 900 computer. For computerized measurement of image features, preprocessing of the original images involved intensity histogram stretching and adjustment of gamma value, brightness and contrast. This enhanced most of the colour contrast of the original sediments with little artificial hues or gradients. From each image the following parameters were analyzed: bottom water oxygen saturation (electrode reading in photograph calibrated against measurements made from a separate bottomwater sample), penetration depth in $\mathrm{cm}$ of the camera pod (as an estimate of shear strength and compaction of the sediment), sediment surface relief (the difference between the highest and lowest overall points in a sediment profile image) as a measure of small-scale sediment structure and biotic activity, depth of the apparent colour redox potential discontinuity layer (RPD) and other laminated sediment structures (Table 1). Visual analysis of the SPI images (Table 2) was done for sediment type (also from the grab samples), occurrence of mollusc shells, surface structures (tubes and/or fauna), subsurface structures (burrows and/or infauna), and the presence of voids (anoxic or oxic; their size and area were estimated) according to Diaz \& Gapcynski (1991), Rumohr \& Schomann (1992) and Diaz et al. (1993). The grouping of stations was done by clustering using SYSTAT 5.0 for Macintosh computers (Euclidian distance using single linkage and the nearest neighbour method based on physical and chemical parameters: depth, oxygen saturation of bottom water, organic content of surface sediment, penetration of camera prism, surface relief, and depth of redox potential discontinuity layer; Burd et al. 1990).

Zoobenthos. In addition to the qualitative analysis of the benthic fauna done in connection with the sediment photography, quantitative data was obtained by grab sampling (5 replicate Ekman-Birge grab samples sieved on a $0.5 \mathrm{~mm}$ screen sampled in June and July 1994; Norkko \& Bonsdorff 1994). The SPI results were compared with the infaunal community data (species, abundance and biomass) through linear regression for the entire range of all data collected. Benthic habitats were compared by 1 -way ANOVA.

\section{RESULTS}

\section{Basic environmental characteristics}

The oxygen saturation correlated negatively with temperature and depth $(\mathrm{p}<0.05$; linear regression analysis). The organic content of the sediment was significantly negatively correlated to the oxygen satura- 
Table 1. Station data and sediment profile lmaging (SPI) results from the 42 stations in the Aland archipelago, northern Baltic Sea, June 1993. Near-bottom oxygen saturation $\left(\mathrm{O}_{2} \%\right)$, sediment type, organic content of the sediment lorg. \%, measured as loss on ignition), penetration depth of the camera prism (PEN), surface relıef (SURF), depth of redox potential discontinuity layer (RPD). Mac: Macoma balthica, Sad: Saduria entomon, Ner: Nereis diversicolor, Chir: Chironomidae, Chir pl: Chironomus plumosustype, Monop: Monoporeia affinis, Olig: Olıgochaeta, Mya: Mya arenaria, Hydr: Hydrobıa spp., Cra: Crangon Crangon, Pyg: Pygospio elegans, Halicr: Halicryptus spinulosus, Myt: Mytilus edulis, -: no data

\begin{tabular}{|c|c|c|c|c|c|c|c|c|c|}
\hline Stn & $\begin{array}{l}\text { Depth } \\
(\mathrm{m})\end{array}$ & $\begin{array}{l}\text { Coordinates } \\
\qquad(N, E)\end{array}$ & $\mathrm{O}_{2} \%$ & $\begin{array}{l}\text { Sediment } \\
\text { type }\end{array}$ & Org. $\%$ & $\begin{array}{l}\text { Dominant } \\
\text { fauna }\end{array}$ & $\begin{array}{l}\text { PEN } \\
(\mathrm{cm})\end{array}$ & $\begin{array}{l}\text { SURF } \\
(\mathrm{cm})\end{array}$ & $\begin{array}{l}\mathrm{RPD} \\
(\mathrm{cm})\end{array}$ \\
\hline 1 & 11 & $60^{\circ} 06^{\prime} 30^{\prime \prime}, \quad 19^{\circ} 55^{\prime} 63^{\prime \prime}$ & 84 & Mud & 9.1 & Mac, Sad, Ner, Chir & 9.5 & 0.8 & 0.7 \\
\hline 2 & 22 & $60^{\circ} 05^{\prime} 03^{\prime \prime}, \quad 19^{\circ} 66^{\prime} 68^{\prime \prime}$ & 89 & Mud & 5.6 & Mac, Monop, Olig, Hydr & 10.7 & 0.9 & 0.7 \\
\hline 3 & 15 & $60^{\circ} 04^{\prime} 45^{\prime \prime}, \quad 19^{\circ} 55^{\prime} 63^{\prime \prime}$ & 86 & Clay & 9.5 & Mac, Chir, Olig, Mya & 3.9 & 2.1 & 0.2 \\
\hline 4 & 5 & $60^{\circ} 05^{\prime} 38^{\prime \prime}, \quad 19^{\circ} 58^{\prime} 05^{\prime \prime}$ & 89 & Mud & 8.2 & Mac, Hydr, Cra, Mya & 8.9 & 1.5 & 0.4 \\
\hline 5 & 28 & $60^{\circ} 05^{\prime} 16^{\prime \prime}, 19^{\circ} 58^{\prime} 86^{\prime \prime}$ & 54 & Mud & 12.4 & Chir pl & 19.1 & 2.0 & 0.4 \\
\hline 6 & 21 & $60^{\circ} 01^{\prime} 86^{\prime \prime}, 20^{\circ} 01^{\prime} 74^{\prime \prime}$ & 81 & Clay & 7.8 & Mac, Monop & 7.8 & 1.0 & 0.5 \\
\hline 7 & 28 & $60^{\circ} 02^{\prime} 35^{\prime \prime}, \quad 19^{\circ} 56^{\prime} 67^{\prime \prime}$ & 84 & Clay/fine sand & 4.5 & Mac, Pyg, Halicr & 5.2 & 0.4 & 0.6 \\
\hline 8 & 19 & $60^{\circ} 05^{\prime} 90^{\prime \prime}, 20^{\circ} 03^{\prime} 78^{\prime \prime}$ & 40 & Mud & 9.1 & Chir pl & 20.1 & 1.5 & - \\
\hline 9 & 9 & $60^{\circ} 16^{\prime} 68^{\prime \prime}, 19^{\circ} 58^{\prime} 52^{\prime \prime}$ & 64 & Mud & 8.3 & Chir pl & 18.1 & 1.8 & - \\
\hline 10 & 14 & $60^{\circ} 15^{\prime} 89^{\prime \prime}, 19^{\circ} 59^{\prime} 37^{\prime \prime}$ & 73 & Mud & 7.6 & Mac, Chir & 14.9 & 1.3 & 1.1 \\
\hline 11 & 17 & $60^{\circ} 14^{\prime} 54^{\prime \prime}, 20^{\circ} 00^{\prime} 61^{\prime \prime}$ & 67 & Mud & 8.9 & Chir pl, Mac & 15.6 & 1.2 & 0.5 \\
\hline 12 & 18 & $60^{\circ} 13^{\prime} 88^{\prime \prime}, 20^{\circ} 01^{\prime} 37^{\prime \prime}$ & 50 & Mud & 8.7 & Chir pl, Mac & 16.1 & 0.9 & 0.3 \\
\hline 13 & 13 & $60^{\circ} 11^{\prime} 06^{\prime \prime}, 20^{\circ} 03^{\prime} 17^{\prime \prime}$ & 75 & Mud/clay & 4.9 & Monop, Chir, Mac, Hydr & 9.9 & 1.0 & 0.6 \\
\hline 14 & 19 & $60^{\circ} 08^{\prime} 85^{\prime \prime}, 20^{\circ} 04^{\prime} 87^{\prime \prime}$ & 73 & Mud/clay & 7.9 & Chir pl & 13.0 & 0.7 & 0.6 \\
\hline 15 & 18 & $60^{\circ} 08^{\prime} 91^{\prime \prime}, 20^{\circ} 07^{\prime} 91^{\prime \prime}$ & 73 & $\mathrm{Mud} / \mathrm{clay}$ & 7.3 & Mac, Monop & 10.5 & 1.1 & 0.5 \\
\hline 16 & 19 & $60^{\circ} 07^{\prime} 48^{\prime \prime}, 20^{\circ} 07^{\prime} 57^{\prime \prime}$ & 83 & Mud & 7.6 & $\mathrm{Mac}$ & 13.4 & 1.0 & 0.6 \\
\hline 17 & 22 & $60^{\circ} 07^{\prime} 91^{\prime \prime}, 20^{\circ} 10^{\prime} 11^{\prime \prime}$ & 79 & Mud & 6.9 & Mac, Monop, Olig & 12.8 & 0.7 & 0.7 \\
\hline 18 & 20 & $60^{\circ} 08^{\prime} 73^{\prime \prime}, 20^{\circ} 09^{\prime} 29^{\prime \prime}$ & 76 & Mud & 7.2 & Monop, Chir pl, Mac & 14.9 & 1.5 & 0.6 \\
\hline 19 & 15 & $60^{\circ} 08^{\prime} 09^{\prime \prime}, 20^{\circ} 10^{\prime} 88^{\prime \prime}$ & 88 & Mud/clay & 5.2 & Monop, Chir pl, Mac & 9.8 & 2.1 & 1.2 \\
\hline 20 & 21 & $60^{\circ} 11^{\prime} 12^{\prime \prime}, 20^{\circ} 12^{\prime} 04^{\prime \prime}$ & 70 & Mud & 6.5 & Mac, Chir, Hydr, Sad & 14.5 & 1.4 & 2.9 \\
\hline 21 & 32 & $60^{\circ} 13^{\prime} 12^{\prime \prime}, 20^{\circ} 17^{\prime} 10^{\prime \prime}$ & 88 & Clay & 7.1 & Monop, Mac, Chir, Olig & 5.8 & 1.4 & 0.3 \\
\hline 22 & 32 & $60^{\circ} 18^{\prime} 40^{\prime \prime}, 20^{\circ} 18^{\prime} 65^{\prime \prime}$ & 82 & Clay/fine sand & 1.9 & Monop, Mac, Halicr, Sad & 1.8 & 0.9 & 1.8 \\
\hline 23 & 32 & $60^{\circ} 21^{\prime} 99^{\prime \prime}, 20^{\circ} 08^{\prime} 70^{\prime \prime}$ & 85 & Mud/clay & 4.6 & Monop, Mac, Halicr & 10.9 & 1.3 & 1.0 \\
\hline 24 & 30 & $60^{\circ} 25^{\prime} 36^{\prime \prime}, 19^{\circ} 45^{\prime} 00^{\prime \prime}$ & 92 & Mud/clay & 1.7 & Mac, Halicr & 4.5 & 0.7 & 0.4 \\
\hline 25 & 27 & $60^{\circ} 24^{\prime} 18^{\prime \prime}, 19^{\circ} 45^{\prime} 34^{\prime \prime}$ & 92 & Mud & 9.7 & Mac, Hydr & 14.2 & 1.4 & 0.6 \\
\hline 26 & 21 & $60^{\circ} 22^{\prime} 88^{\prime \prime}, \quad 19^{\circ} 46^{\prime} 09^{\prime \prime}$ & 93 & Mud & 10.8 & Mac & 13.5 & 0.9 & 0.6 \\
\hline 27 & 14 & $60^{\circ} 22^{\prime} 01^{\prime \prime}, \quad 19^{\circ} 45^{\prime} 95^{\prime \prime}$ & 89 & Mud & 5.8 & $\mathrm{Mac}$ & 10.0 & 1.0 & 1.0 \\
\hline 28 & 12 & $60^{\circ} 21^{\prime} 27^{\prime \prime}, \quad 19^{\circ} 47^{\prime} 12^{\prime \prime}$ & 93 & Mud & 9.3 & $\mathrm{Mac}, \mathrm{Ch} \mathrm{pl}$ & 16.8 & 2.4 & 0.7 \\
\hline 29 & 12 & $60^{\circ} 21^{\prime} 15^{\prime \prime}, \quad 19^{\circ} 46^{\prime} 94^{\prime \prime}$ & - & Mud & 10.1 & $\mathrm{Mac}, \mathrm{Ch} \mathrm{pl}$ & 18.0 & 1.3 & 0.5 \\
\hline 30 & 14 & $60^{\circ} 20^{\prime} 87^{\prime \prime}, 19^{\circ} 46^{\prime} 87^{\prime \prime}$ & - & Mud & 9.6 & $\mathrm{Ch} \mathrm{pl}$ & 18.0 & 2.8 & 0.7 \\
\hline 31 & 15 & $60^{\circ} 19^{\prime} 99^{\prime \prime}, 19^{\circ} 46^{\prime} 85^{\prime \prime}$ & 82 & Mud/clay/stones & 2.8 & Mac, Chir & 2.7 & 2.8 & 0.2 \\
\hline 32 & 26 & $60^{\circ} 17^{\prime} 71^{\prime \prime}, 19^{\circ} 47^{\prime} 91^{\prime \prime}$ & 61 & Mud & 8.9 & $\mathrm{Mac}, \mathrm{Ch} \mathrm{pl}$ & 15.8 & 1.6 & 0.7 \\
\hline 33 & 8 & $60^{\circ} 16^{\prime} 50^{\prime \prime}, \quad 19^{\circ} 47^{\prime} 99^{\prime \prime}$ & 83 & Mud & 7.2 & $\mathrm{Mac}, \mathrm{Ch} \mathrm{pl}$ & 14.0 & 0.9 & 0.5 \\
\hline 34 & 7 & $60^{\circ} 21^{\prime} 41^{\prime \prime}, 19^{\circ} 42^{\prime} 21^{\prime \prime}$ & 92 & Medium sand & 0.8 & Mac, Pyg, Hydr, Mya & 1.4 & 1.0 & 1.4 \\
\hline 35 & 35 & $60^{\circ} 21^{\prime} 74^{\prime \prime}, 19^{\circ} 40^{\prime} 94^{\prime \prime}$ & 87 & Mud & 9.5 & $\mathrm{Mac}$ & 13.2 & 1.1 & 0.5 \\
\hline 36 & 32 & $60^{\circ} 23^{\prime} 77^{\prime \prime}, 19^{\circ} 38^{\prime} 24^{\prime \prime}$ & 87 & Medium sand/clay & 0.9 & Monop, Mac, Pyg & 10.7 & 1.1 & 3.1 \\
\hline 37 & 7 & $60^{\circ} 23^{\prime} 80^{\prime \prime}, 19^{\circ} 40^{\prime} 15^{\prime \prime}$ & 93 & Medium sand & 0.5 & Mac, Pyg & 0.3 & 0.8 & 0.3 \\
\hline 38 & 25 & $60^{\circ} 19^{\prime} 99^{\prime \prime}, 19^{\circ} 30^{\prime} 83^{\prime \prime}$ & 89 & Medium sand & 0.6 & Mac, Monop, Pyg, Halicr & 2.3 & 0.7 & 2.3 \\
\hline 39 & 25 & $60^{\circ} 13^{\prime} 10^{\prime \prime}, 19^{\circ} 29^{\prime} 00^{\prime \prime}$ & 87 & Medium sand & 1.8 & Mac, Monop, Halicr & 0.4 & 0.6 & 0.4 \\
\hline 40 & 13 & $60^{\circ} 13^{\prime} 55^{\prime \prime}, 19^{\circ} 31^{\prime} 01^{\prime \prime}$ & 89 & Fine sand & 1.4 & Pyg, Mac, Myt & 1.2 & 0.6 & 1.2 \\
\hline 41 & 263 & $60^{\circ} 09^{\prime} 86^{\prime \prime}, 19^{\circ} 08^{\prime} 58^{\prime \prime}$ & - & Mud/clay & - & - & 15.8 & 1.5 & 0.7 \\
\hline 42 & 130 & $60^{\circ} 06^{\prime} 78^{\prime \prime}, 18^{\circ} 56^{\prime} 72^{\prime \prime}$ & - & Mud/clay & - & - & 7.6 & 1.0 & 1.9 \\
\hline
\end{tabular}

tion of the near-bottom water $(p<0.05)$. The oxygen conditions are partly explained by depth and temperature, but also by exposure, with high oxygen saturations at open coastal stations and reduced oxygen conditions at sheltered inshore localities (Table 1). The sediment at the investigated stations is dominated by mud (at $74 \%$ of the stations at 5 to $263 \mathrm{~m}$; Table 1), clay $(36 \%, 15$ to $263 \mathrm{~m})$, and sandy habitats $(19 \%, 7$ to $32 \mathrm{~m})$

\section{Sediment surface and profile imaging}

The grouping (clustering) of stations delimited 4 distinct habitats (Fig. 1, Table 3): inner bays and sheltered archipelago waters ( 8 stations), archipelago areas $(20$ stations), the open coastal zone (12 stations), and the open sea (2 stations). The open coastal zone was deeper than the archipelago zone, but the difference was only a few meters. The oxygen saturation varied 
Table 2. Visual analysis of the sediment profile images from the the 42 stations in Aland archipelago, June 1993 ( $\mathrm{n}=1-3$ per station). NA: not analyzable, +: present, -: not present

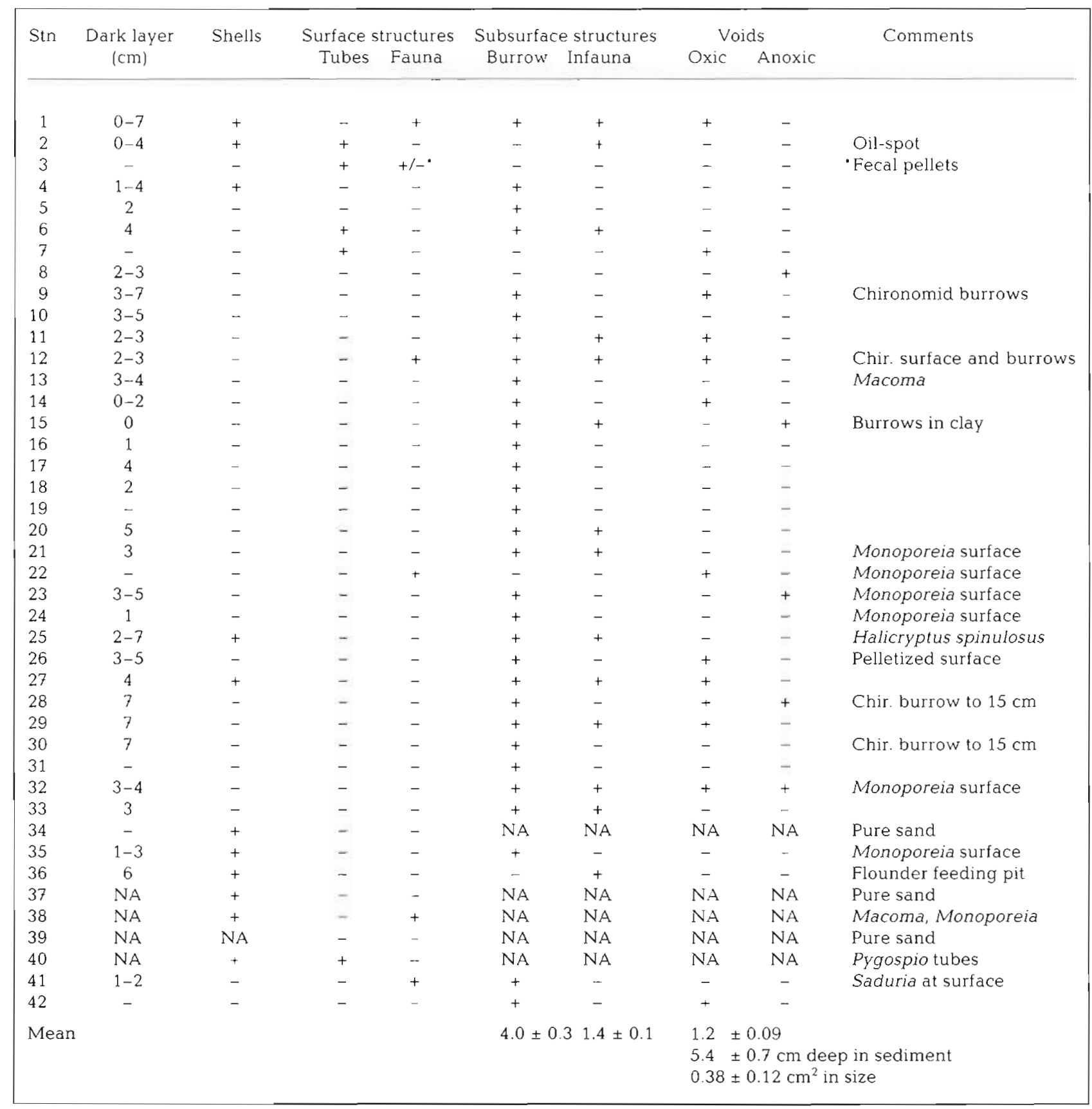

significantly between zones (the inner bays had lower values than the other 2 areas; $p<0.05 ; 1$-way ANOVA). SPI-parameters displayed significant differences between zones; penetration and surface relief both decreased while the depth of the RPD layer increased from the inner bays towards the open coast (p<0.05),

The visual analysis of the sediment surface and profile images (Table 2) showed that shells were regis- tered in the sediment at $26 \%$ of the stations, primarily at sandy bottoms with low penetration depth (Stns 34 to 39). Surface tubes (mainly from small polychaetes such as Pygospio elegans) were noted at 5 stations in the Mariehamn-area (Stns 2 to 7), which are influenced by frequent ferry traffic regularly disturbing the sediment surface through increased turbulence (Norkko \& Bonsdorff 1994). Fauna at the sediment surface was recorded at 6 stations of varying depth and sediment 
Table 3. Grouping of the 42 stations in the Aland archipelago based on physical and chemical parameters: depth, oxygen saturation of bottom water ( $\%)$, occurrence of seasonal hypoxia (+ or -), organic content of surface sediment (\%), penetration of camera $(\mathrm{cm})$, surface relief $(\mathrm{cm})$, and depth of redox potential discontinuity layer $(\mathrm{cm})$. All values are averages \pm 1 SE. Faunal data from Norkko \& Bonsdorff (1994)

\begin{tabular}{|c|c|c|c|c|}
\hline $\begin{array}{l}\text { Area: } \\
\text { (Stns) }\end{array}$ & $\begin{array}{l}\text { Inner archipelago } \\
(5,8,9,12 \\
28,29,30,32)\end{array}$ & $\begin{array}{l}\text { Archipelago } \\
(1,2,3,4,6,10,11 \\
13,14,14,16,17,18 \\
19,20,25,26,27,31,33)\end{array}$ & $\begin{array}{l}\text { Open coastal zone } \\
\{7,21,22,23,24 \\
34,35,36,37 \\
38,39,40\}\end{array}$ & $\begin{array}{l}\text { Open sea } \\
(41,42)\end{array}$ \\
\hline Depth $(\mathrm{m})$ & $17.3 \pm 2.4$ & $16.9 \pm 1.2$ & $24.8 \pm 2.9$ & 197 \\
\hline Oxygen saturation $(\%)$ & $60.6 \pm 7.3$ & $81.5 \pm 1.7$ & $88.1 \pm 1.0$ & Oxic \\
\hline Seasonal hypoxia $(+/-)$ & + & + & - & - \\
\hline Organic content $(\%)$ & $9.6 \pm 0.5$ & $7.3 \pm 0.4$ & $2.9 \pm 0.8$ & Mud/clay \\
\hline Sediment type & Mud & Mud/clay & Sand/clay & $\mathrm{Mud} / \mathrm{clay}$ \\
\hline Penetration $(\mathrm{cm})$ & $17.8 \pm 0.6$ & $11.2 \pm 0.8$ & $4.8 \pm 1.8$ & 11.7 \\
\hline Surface relief $(\mathrm{cm})$ & $1.8 \pm 0.2$ & $1.3 \pm 0.1$ & $0.9 \pm 0.009$ & 1.3 \\
\hline RPD layer $(\mathrm{cm})$ & $0.4 \pm 0.1$ & $0.7 \pm 0.1$ & $1.1 \pm 0.3$ & 1.3 \\
\hline No. of species: & $9.0 \pm 1.7$ & $9.4 \pm 1.0$ & $10.4 \pm 1.4$ & NA \\
\hline Dominant species & Macoma, Chironomus & Macoma, Monoporeia & Monoporeia, Macoma & \\
\hline Abundance (ind ${ }^{-2}$ ) & $2816 \pm 531$ & $2340 \pm 756$ & $7872 \pm 2199$ & NA \\
\hline Biomass ( $g$ wet wt $\mathrm{m}^{-2}$ ) & $125.8 \pm 39.4$ & $120.4 \pm 38.1$ & $196.7 \pm 45.6$ & NA \\
\hline
\end{tabular}

quality. The animals registered were the bivalve $M a-$ coma balthica, the crustaceans Saduria entomon (surface image at Stn 41), Monoporeia affinis and Idotea balthica, and chironomid larvae. Surface images also showed feeding pits of flounder Platichthys flesus on sandy bottoms (Fig. 2). Subsurface structures were common in images, with distinct burrows appearing at 31 of the stations (on average $4.0 \pm 0.3$ burrows per image when present; Table 2). The burrows appeared to be constructed by $M$. balthica, amphipods, polychaetes and chironomid larvae, and penetrated to a maximum depth of $15 \mathrm{~cm}$ in the sediment. In 2 instances adult $M$. balthica were seen in the burrows (Fig. 2). The burrows were recorded mainly at Stns 9 to 20 on central Aland and 25 to 32 in the northwestern archipelago (Tables $1 \& 2$ ). Both areas are sheltered and dominated by soft bottoms. Infauna $(1.4 \pm 0.13$ individuals per image when present; chironomids, unidentified worms, M. balthica and the priapulid Halicryptus spinulosus) was seen in the images from 14 stations from all areas (except the sandy bottoms with low penetration). Voids (anoxic or oxic) were recorded at 16 stations $(1.2 \pm 0.09$ per frame when present). They were on average $0.38 \pm$ $0.12 \mathrm{~cm}^{2}$ in size and situated $5.4 \pm 0.7 \mathrm{~cm}$ below the sediment surface. At some stations ( 21 to 24,32 and 35 ; Table 2), burrows of the amphipod $M$. affinis were abundant at the surface layer of the sediment 10 to $3 \mathrm{~cm}$ ), and the sediment surface was well bioturbated.

\section{Benthic infauna}

The qualitative samples taken in connection with the SPI analysis (Table 1) showed no major differences in faunal dominance in the various areas. The fauna was dominated by Macoma balthica, Monoporeia affinis and chironomid larvae. The quantitative sampling (Table 3) showed that the number of species and total community biomass did not differ between groups of stations (Table 3, and Norkko \& Bonsdorff 1994). Total abundance was significantly ( $p<0.05,1$-way ANOVA) higher in the open coastal zone, where the sandy bottoms were dominated by amphipods (primarily Monoporeia affinis) and the polychaete Pygospio elegans.

\section{DISCUSSION}

\section{Using SPI in the northern Baltic Sea}

The SPI methodology has previously been used mainly in monitoring pollution and organic enrich-

Fig. 2. Sediment surface and profile imaging. (a) SPI from Stn 26, enhanced as it would be for computerized measurement, revealing muddy sediments, an average redox potential discontınuity (RPD) layer depth of $0.6 \mathrm{~cm}$, and a faırly rough, biologically reworked surface. (b) Enlargement of a SPI from Stn 11, revealing 2 chironomid larvae (reddish coloured) and oxidized sediments associated with recent burrowing activity. (c) Enlargement of a profile image from $S \operatorname{tn} 36$ with a crushed Macoma balthica shell next to what is believed to be a flounder feeding pit. (d) Enlargement of a profile image from Stn 25, where 2 of the priapulid Halicryptus spinulosus were revealed by image enhancement 
(a) Sediment profile image (enhanced)

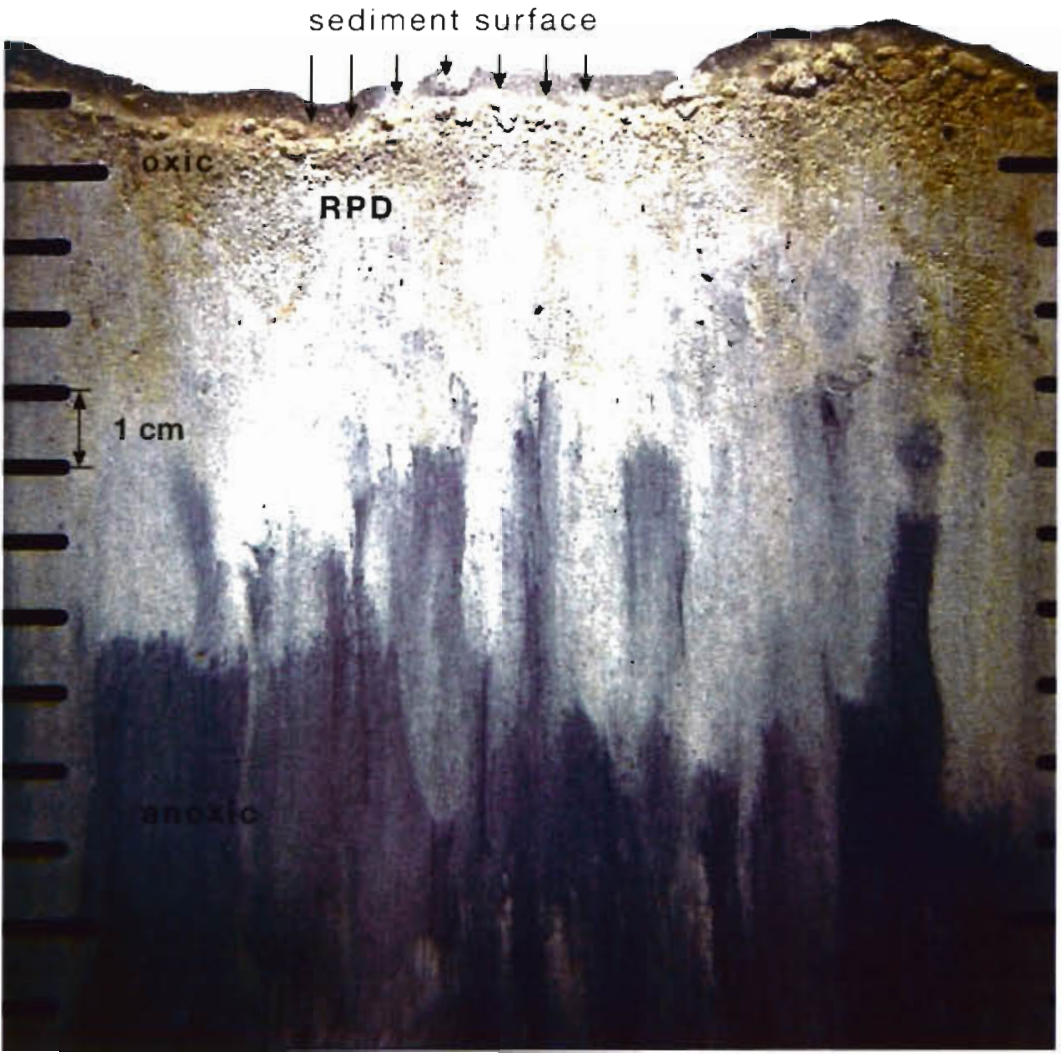

(b) Chironomid larvae

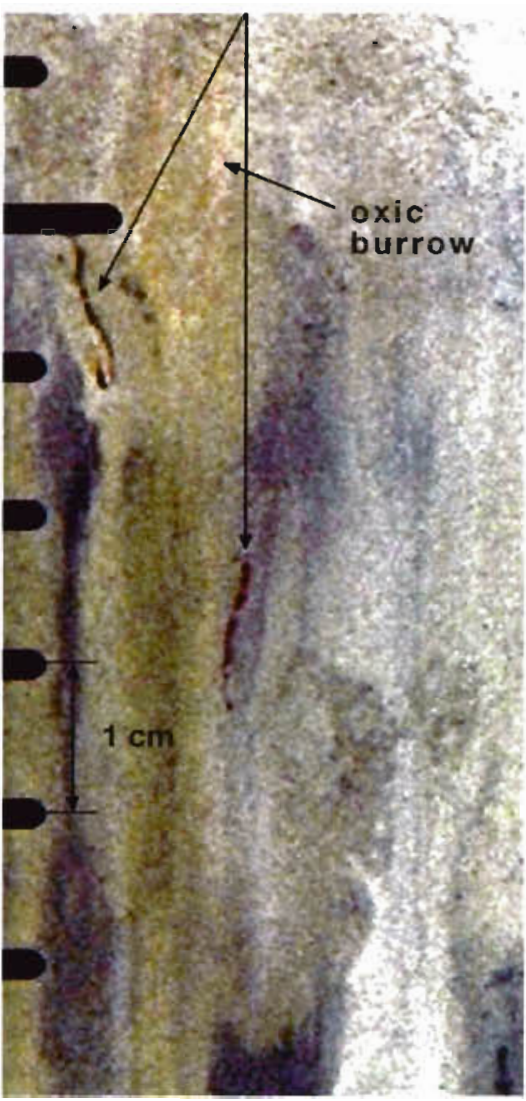

(c) Bivalve shell (Macoma balthica)

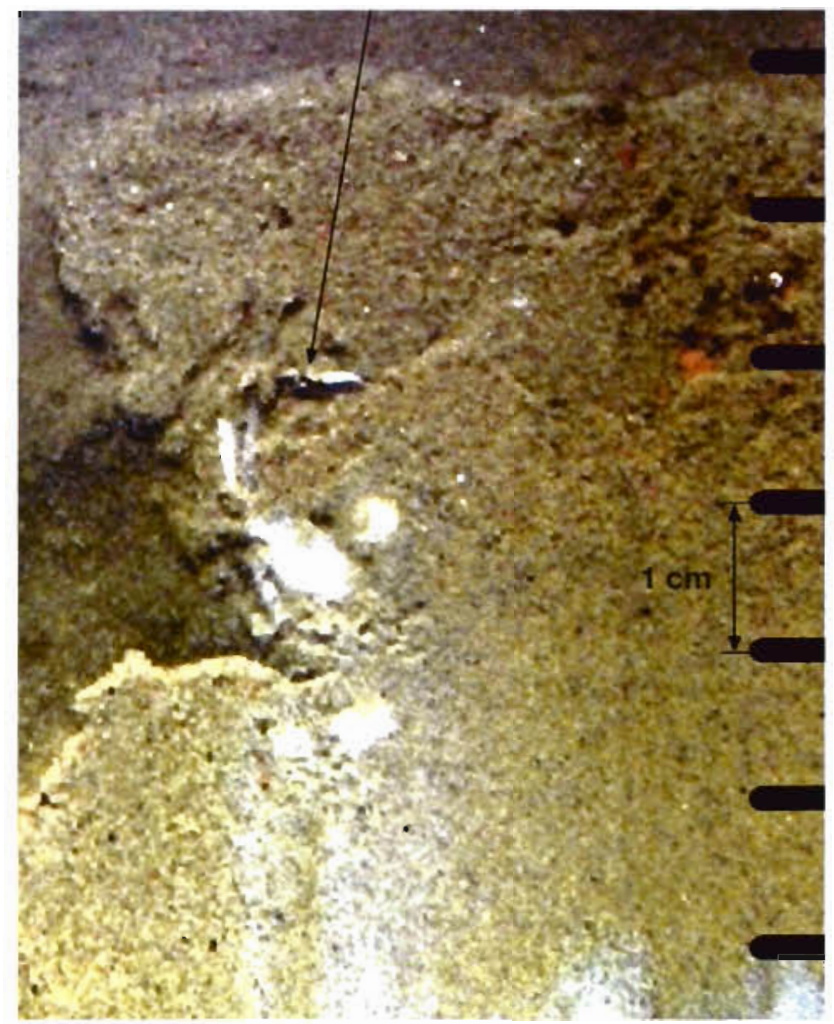

(d) Halicryptus spinulosus

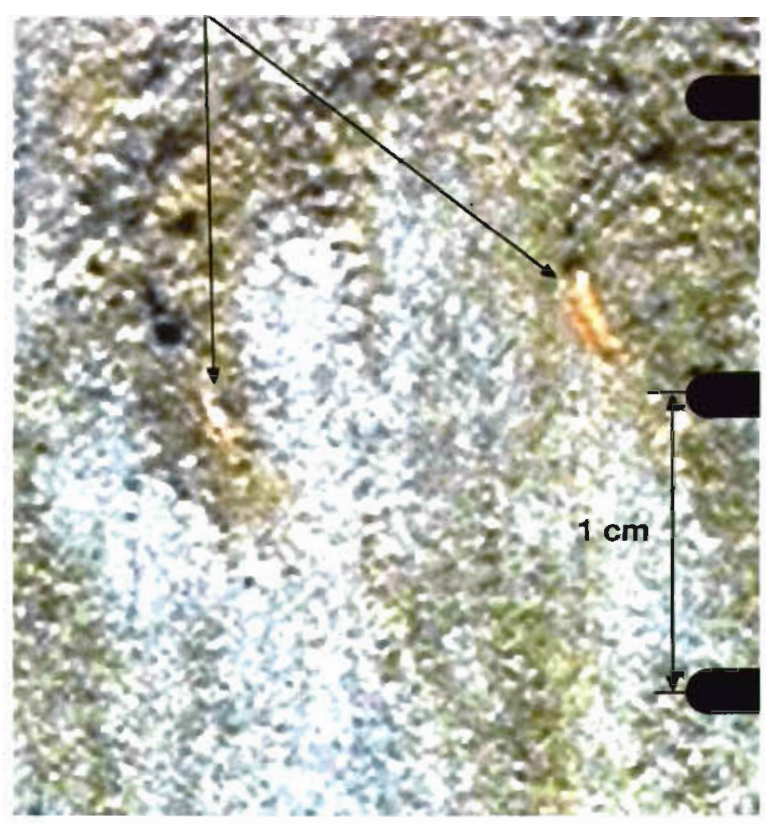


ment and in mapping sediment habitats (Rhoads \& Germano 1986, Valente et al. 1992, Diaz et al. 1993. Rumohr 1993). It has often been linked to an Organism-Sediment Index (OSI) and to apparent successional stages (sensu Pearson \& Rosenberg 1978) of the infauna (Valente et al. 1992) as suggested by Rhoads \& Germano $(1982,1986)$. In the northern Baltic Sea these criteria are not as easily applicable as they might be in organically enriched marine soft sediments where changes in size distribution among the sediment-dwelling infauna is an apparent effect of changes in the benthic habitats. In the Baltic Sea most infaunal organisms are small and most of the biomass is found in the top few $\mathrm{cm}$ of the sediment (Dold 1980, Romero 1983, Hill \& Elmgren 1987). Further, the deep areas are often structured by periodic anoxia (Andersin \& Sandler 1989, 1991), emphasizing the importance of the coastal and archipelago areas for benthic production (Elmgren 1984, Bonsdorff \& Blomqvist 1993). The basic sediment types in the northern Baltic Sea are glacial clay covered by mud or sand, or substrates dominated by coarse sand, gravel and nodules of ferro-manganese (Voipio 1981). The RPD is located close to the sediment surface in the northern Baltic Sea; this is due to the lack of deep-burrowing animals, rather than just organic enrichment (Rosenberg \& Diaz 1993, Rumohr et al. 1996). Hence, the SPI methodology and habitat characterization benefit from being associated with hydrographical, chemical and biological methods. Snelgrove \& Butman (1994) concluded that the organic content of the sediment seems to be a more likely causal factor than grain size (sediment type) for the infauna, and Pearson \& Rosenberg $(1978,1987)$ illustrated similar aspects. Grizzle \& Penniman (1991) also showed that the SPI is useful as a tool along an enrichment gradient, illustrating the links between organic content, RPD, and infauna, and Rosenberg (1995) linked sediment characteristics and camera image observations to the distribution of faunal communities. Hence, parameters found to correlate significantly with organic content would be of prime interest from the SPI analysis.

Jonsson \& Carman (1994) found that the organic content of the sediment has increased more than 1.7 -fold in the Baltic since the 1920s, which would partly explain long-term changes (primarily increasing abundance and biomass) in the zoobenthos recorded in the archipelago areas (Bonsdorff et al. 1991, 1992, 1997. Norkko \& Bonsdorff 1994). Their estimate of the average organic content (loss on ignition) for the Bothnian Sea adjacent to the Aland archipelago is very close to our estimate $(8.3 \pm 1.4 \%$ in their study from the open sea vs $6.5 \pm 0.5 \%$ in our analysis of coastal and archipelago waters).

\section{Sediment characteristics, hydrography and infauna}

Penetration of the prism is highly dependent on the sediment type, with little or no penetration in sandy sediments and down to $20 \mathrm{~cm}$ in soft mud (Table 1). The apparent colour RPD is shallow $10.8 \pm 0.1 \mathrm{~cm}$, total mean), which is not only a result of low oxygen levels, but primarily of the lack of large sediment dwelling organisms that would rework the sediment. Thus, the use of the OSI as proposed by Rhoads \& Germano (1982, 1986), Valente et al. (1992), and Nilsson \& Rosenberg (1995) is not directly applicable in the Baltic Sea, mainly due to the absence of a late successional stage fauna. Low salinity, sediment type, and organic enrichment are all factors contributing to the lower successional stage fauna in the Baltic Sea (Pearson \& Rosenberg 1978, Bonsdorff \& Blomqvist 1993, Bonsdorff et al. 1997). Among the environmental parameters, oxygen saturation is of prime importance, and hypoxia (or periodic oxygen deficiency) seems to be a main factor structuring benthic communities (Rosenberg \& Loo 1988, Andersin \& Sandler 1991, Schaffner et al. 1992, Diaz \& Rosenberg 1995). However, areas which sustain macrofauna may be in close proximity to areas with anoxic sediments devoid of macrofauna and covered by bacterial mats (Rosenberg \& Diaz 1993. Diaz \& Rosenberg 1995).

Comparing the SPI analysis from the non-polluted but clearly eutrophic Aland archipelago with the polluted and highly eutrophic inner Stockholm archipelago, northern Baltic Sea, where the sediments were largely anoxic (Rosenberg \& Diaz 1993) showed that the main difference in visual sediment properties was in the frequency of feeding voids. A higher frequency was recorded in the present study; and, as these voids are linked to burrowing infauna, the difference is expected. Based on the present SPI analysis, the sediment habitats of the Aland archipelago, although significantly affected by eutrophication (Bonsdorff et al. 1991, 1992, 1997, Norkko \& Bonsdorff 1994), are not yet hypertrophic. The major exceptions, grouped as 'inner archipelago' (Table 3), are stations situated in the vicinity of fish farms (Stns 28,29 and 30), in enclosed bays surrounded by extensive farming and large drainage areas (Stns 8, 9, and 12), and stagnating basins in enclosed areas (Stns 5, and 32), i.e. areas close to local point sources of excess nutrients (Bonsdorff et al. 1991, 1992). These areas show some similarity to the stressed habitats of the Stockholm archipelago as described by Rosenberg \& Diaz (1993). The overall long-term trend in the area shows a significant increase $(p<0.01,1$-way ANOVA) in abundance and biomass of the zoobenthos from the 1970s to the 1990s (Norkko \& Bonsdorff 1994, Bonsdorff et al. 1997), with seasonal (annual) changes generally being small (Bonsdorff \& Blomqvist 1989). 
In situ observation of the geological and biological aspects of sediment fabric using SPI (for example, sediment laminations, shells, tubes, burrows, infauna, and voids) provides additional information that traditional faunal sampling and rough sediment analysis cannot provide (Grizzle \& Penniman 1991, Diaz et al. 1993). While grab samples confirmed the presence of the amphipods Monoporeis affinis and Pontoporeia femorata, SPI determined the importance of these amphipods to surface sediment reworking of Baltic sediments (Hill \& Elmgren 1987, Lopez \& Elmgren 1989, Lehtonen 1995). The chironomid burrows observed down to $15 \mathrm{~cm}$ in the soft muddy habitats with low oxygen content illustrate the role of burrowers in oxygenating deep layers of the sediment and participating in the remineralization of nutrients from the sediment to the water column (Leppäkoski 1975, Rosenberg et al. 1975, Pearson \& Rosenberg 1978, Diaz $\&$ Rosenberg 1995). Seasonality in abundance and biomass of the chironomid larvae in the Aland region is marked, and large seasonal variations in their role as bioturbators can be expected (Bonsdorff \& Storberg 1990). Chironomus plumosus larvae contain haemoglobin in their blood and are well adapted for hypoxic conditions, and they are known to favour soft sediments rich in organic matter, although little is known about their tube-building behaviour (McLachlan \& Cantrell 1976, Koskenniemi 1994). Diaz et al. (1993) illustrated similar conditions regarding the detection of opportunistic spionid polychaetes that in some ways are equivalent to the chironomid burrows seen in the present images. The bulldozing tracks left by the isopod Saduria entomon underline the importance of the role of the biotic activity by this large isopod for the sediment surface at deep water stations (Haahtela 1990, Vismann 1991, Sandberg 1994, Sandberg \& Bonsdorff 1996).

\section{Concluding remarks}

The SPI methodology proved very useful in describing and classifying the sediment habitats in the archipelago areas of the brackish Baltic Sea. The method is easy and cheap to use and gives rapid results. In combination with the information on basic hydrography (primarily oxygen saturation of the bottom water), sediment chemistry (organic content of the surface sediment), and quantitative information on the benthic infauna (including information on bioturbation), clear groupings of the environment could be made. Such groupings can be of great value when comparing the Baltic ecosystem with other sea areas analysed by imaging techniques (Hongguang et al. 1995, Rumohr et al. 1996). As the main parameters showed significant correlations both within methods (the SPI data) and between biotic (zoobenthos) and abiotic environmental information, we conclude that the method used here added valuable knowledge to our understanding of the structuring and distribution of the benthic communities. Also, from an environmental monitoring point of view, the sediment surface and profile imaging clearly demonstrated its potential as a rapid means of classifying and grouping large areas of varying depth, exposure, and degree of human impact (Rumohr et al. 1996). The high levels of correlation between the SPI analysis and the traditional information is encouraging for future application of sediment surface and profile imaging in the Baltic Sea, providing the possibility of direct and rapid comparison with other areas impacted to varying degrees by human activity and with radically different aquatic environments.

Acknowledgements. We thank. Per Jonsson and the crew of the R/V 'Sunbeam' for excellent working conditions during the SPI analysis in the Aland archipelago. We also thank the Academy of Finland for financial support. Comments by Brendan Keegan, Tom Pearson, and Heye Rumohr on an earlier draft are gratefully acknowledged.

\section{LITERATURE CITED}

Andersin $A B$, Sandler H (1989) Occurrence of hydrogen sulphide and low oxygen concentrations in the Baltic deep basins. Proc 16th Conf Baltic Oceanographers Vol 1. Swedish Meteorological and Hydrological Institute, Norrköping, p 102-111

Andersin AB, Sandler H (1991) Macrobenthic fauna and oxygen deficiency in the Gulf of Finland. Mem Soc Fauna Flora Fenn 67:3-10

Bonsdorff E, Aarnio K, Lindell A, Sandberg E (1992) Longterm changes in the archipelago waters of Aland - a comparison of the zoobenthos 1972-1990. Mem Soc Fauna Flora Fenn 68:1-9 (in Swedish with English summary)

Bonsdorff E, Aarnio K, Sandberg E (1991) Temporal and spatial variability of zoobenthic communities in the archipelago waters of the northern Baltic Sea-consequences of eutrophication? Int Rev Ges Hydrobiol 76:433-449

Bonsdorff E, Blomqvist EM (1989) Do exceptional winters affect zoobenthos and fish in shallow, brackish archipelago waters? An example from the northern Baltic Sea. Mem Soc Fauna Flora Fenn 65:47-53

Bonsdorff E, Blomqvist EM (1993) Biotic couplings on shallow water soft bottoms-examples from the northern Baltic Sea. Oceanogr Mar Biol Annu Rev 31:153-176

Bonsdorff E, Blomqvist EM, Mattila J, Norkko A (1997) Longterm changes and coastal eutrophication. Examples from the Aland Islands and the Axchipelago Sea, northern Baltic Sea. Oceanol Acta 20:in press

Bonsdorff E, Storberg K-E (1990) Ecological changes in a formerly meromictic coastal lake. Limnologica 20:279-284

Burd BJ, Nemec A, Brinkhurst RO (1990) The development and application of analytical methods in benthic marine infaunal studies. Adv Mar Biol 26:169-247

Carlsson B, Bergstrom S (1993) Hydrology of the Baltic basin. Inflow of fresh water from rivers and land for the period 1950-1990. Swedish Meteorological and Hydrological Institute, Norrköping, SMHI Reports Hydrology 7:1-21 
Cederwall H. Elmgren R (1990) Biological effects of eutrophication in the Baltic Sea, particularly the coastal zone. Ambio 19:109-112

Diaz. RJ, Gapcynski P (1991) Sediment surface and profile image (SPl) analysis applied to the rapid assessment of benthic habitats. In: Keegan B (ed) COST 647 Coastal Benthic Ecology. Activity Report 1988-1991. CEC DG XII, p 319-322

Diaz RJ, Hansson LJ, Rosenberg R, Gapcynski PC, Unger MA (1993) Rapid sedimentological and biological assessment of hydrocarbon contaminated sediments. Water Air Soil Pollut 66:251-266

Diaz RJ, Rosenberg R (1995) Marine benthic hypoxıa: ecological effects and behavioural responses of benthic macrofauna. Oceanogr Mar Biol Annu Rev 33:245-303

Dold R (1980) Zur Ökologie, Substratspezifität und Bioturbation von Makrobenthos auf Weichboden der Kieler Bucht. PhD thesis, University of Kiel, Germany

Elmgren R (1984) Trophic dynamics in the enclosed, brackish Baltic Sea. Rapp PV Réun Cons Int Explor Mer 183: $152-169$

Graf G (1992) Benthic-pelagic coupling: a benthic view. Oceanogr Mar Biol Annu Rev 30:149-190

Grehan AJ, Keegan BF, Bhaud M, Guille A (1992) Sediment profile imaging of soft substrates in the western Mediterranean: the extent and importance of faunal reworking. C R Acad Sci Paris Ser III Sci Vic 315:309-31.5

Grizzle RE, Penniman CA (1991) Effects of organic enrichment on estuarine macrofaunal benthos: a comparison of sediment profile imaging and traditional methods. Mar Ecol Prog Ser 74:249-262

Haahtela I (1990) What do Baltic studies tell us about the isopod Saduria entomon? Ann Zool Fenn 27:269-278

HELCOM (1993) First assessment of the state of the coastal waters of the Baltic Sea. Baltic Sea Environm Proc, Baltic Marine Environment Protection Commission-Helsinki Commission 54

Hill C, Elmgren R (1987) Vertical distribution in the sediment in the co-occurring amphipods Pontoporeia affinis and P. femorata. Oikos 49:221-229

Hongguang $M$, Zhiying $Y$, Cadée GC (1995) Macrofauna distribution and bioturbation on tidal confluences of the Dutch Wadden Sea. Neth J Aquat Ecol 29:167-176

Jonsson P, Carman R (1994) Changes in deposition of organic matter and nutrients in the Baltic Sea during the twentieth century. Mar Pollut Bull 28:417-426

Jonsson P, Carman R, Wulff F (1990) Laminated sediments in the Baltic Sea - a tool for evaluating mass balance. Ambio 19:152-158

Jumppanen K, Mattila J (1994) The development of the state of the Archipelago Sea and environmental factors affecting it. Lounais-Suomen Vesiensuojeluyhd Julk 82:1-206

Koskenniemi E (1994) Colonization, succession and environmental conditions of the macrozoobenthos in a regulated. polyhumic reservoir, western Finland. Int Rev Ges Hydrobiol 79:521-555

Lehtonen K (1995) Geographical variability in the bioenergetic characteristics of Monoporeia/Pontoporela spp. populations from the northern Baltic Sea, and their potential contribution to benthic nitrogen mineralization. Mar Biol 123:555-564

Leivuori M, Niemistö L (1993) Trace metals in the sediments of the Gulf of Bothnia. Aqua Fenn 23:89-100

Leppäkoski E (1975) Assessment of degree of pollution on the basis of macrozoobenthos in marine and brackish-water environments. Acta Acad Abo, Ser B 35:1-90

Leppäkoski E, Bonsdorff E (1989) Ecosystem variability and gradients. Examples from the Baltic Sea as a background for hazard assessment. In: Landner L (ed) ChemicaIs in the aquatic environment. Advanced Hazard Assessment. Springer Verlag, Berlin, p 6-58

Lopez G, Elmgren R (1989) Feeding depth and organic absorption for the deposit-feeding benthic amphipods Pontoporeia affinis and Pontoporeia femorata. Limnol Oceanogr 34:982-991

McLachlan AJ, Cantrell MA (1976) Sediment development and its influence on the distribution and tube structure of Chironomus plumosus L. (Chironomidae, Diptera) in a new impoundment. Freshwat Biol 6:437-443

Niemistö L, Winterhalter B (1977) Bottom photography used to study oxygen conditions in the northern Baltic Sea. Merntutkimuslait Julk/Havsforskningsinst Skr 241. $91-95$

Nilsson HC, Rosenberg R (1995) Miljöbedömning och karakterisering av Havstensfjord - en syrestressad fjord analyserad med undervattensteknik. Länsstyrelsen i Göteborgs och Bohus län, Publikation 1995 24:1-1.1

Norkko A, Bonsdorff E (1994) Zoobenthos and hydrography in the transition-zone between the shallow coastal bottoms and the open sea in the Aland archipelago, N. Baltic Sea. Forskningsrapporter fran Husö biol stat 91:1-44 (in Swedish with English summary)

O'Connor BDS, Costelloe J, Keegan BF, Rhoads DC (1989) The use of REMOTS ${ }^{\circledR}$ technology in monitoring coastal enrichment from mariculture. Mar Pollut Bull 20:384-390

Pearson TH, Rosenberg R (1978) Macrobenthic succession in relation to organic enrichment and pollution of the marine environment. Oceanogr Mar Biol Annu Rev 16:229-311

Pearson TH, Rosenberg R (1987) Feast and famine: structuring factors in marine benthic communities. In: Gee JHR, Giller PS (eds) Organization of communities past and present. Blackwell Scientification Publication, Oxford, p 373-395

Pitkänen H (1994) Eutrophication of the Finnish coastal waters. origin, fate and effects of riverine nutrient fluxes. Publ Water Environ Res Inst 18:1-44

Rhoads DC, Cande S (1971) Sediment profile camera for in situ study of organism-sediment relations. Limnol Oceanogr 16:110-114

Rhoads DC, Germano JD (1982) Characterization of organism-sediment relations using sediment profile imaging: an efficient method of remote ecological monitoring of the seafloor (Remots ${ }^{\text {IM }}$ system). Mar Ecol Prog Ser 8:115-128

Rhoads DC, Germano JD (1986) Interpreting long-term changes in benthic community structure: a new protocol. Hydrobiologia 142:291-308

Romero M (1983) Vertikale Verteilungsmuster der Macrofauna im Sediment. MSc thesis, University of Kiel, Germany

Rosenberg R (1995) Benthıc marine fauna structured by hydrodynamic processes and food avallability. Neth J Sea Res 34.303-317

Rosenberg R, Diaz RJ (1993) Sulphur bacteria (Beggiatoa spp.) mats indicate hypoxic conditions in the nner Stockholm archipelago. Ambio 22:32-36

Rosenberg R, Loo LO (1988) Marine eutrophication induced oxygen deficiency: effects on soft bottom fauna, western Sweden. Ophelia 29:213-225

Rosenberg R, Nilsson K, Landner L (1975) Effects of a sulphite pulp mill on the benthic macrofauna in a firth of the Bothnian Sea. Merentutkimuslait Julk/Havsforsknungsinst Skr 239:289-300

Rumohr H (1993) Erfahrungen und Ergebnisse aus 7 Jahren Benthosmonitoring in der südlichen Ostsee. In: Duinker 
JC (ed) Das Biologische Monitoring der Ostsee im lnstitut für Meereskunde 1985-1992. Ber Inst Meeresk Kiel 240: $90-109$

Rumohr $H_{1}$ Bonsdorff E, Pearson TH (1996) Zoobenthic succession in Baltic sedimentary habitats. Arch Fish Mar Res (in print)

Rumohr H, Schomann H (1992) REMOTS sediment profiles around an exploratory drilling rig in the southern North Sea. Mar Ecol Prog Ser 91:303-311

Rumohr H, Schomann H, Kujawski T (1992) Sedimentological effects of the Great Belt crossing as revealed by REMOTS photography. In: Bjornestad E, Hagerman L, Jensen K (eds) Proc 12th Baltic Marine Biologists Symp. Olsen \& Olsen, Fredensborg, p 135-139

Sandberg E (1994) Does short-term oxygen depletion affect predator-prey relationships in zoobenthos? Experiments with the 1sopod Saduria entomon. Mar Ecol Prog Ser 103: $73-80$

Sandberg E, Bonsdorff E (1996) Effects of predation and oxygen deficiency on different age classes of the amphipod Monoporeia affinis. J Sea Res 35:345-351

This article was presented by J. Gray (Senior Editorial Advisor), Oslo, Norway
Schaffner L, Jonsson P, Diaz RJ, Rosenberg R, Gapcynski P (1992) Benthic communities and bioturbation history of estuarine and coastal systems: effects of hypoxia and anoxia. Sci Total Environ Suppl 1992:1001-1016

Snelgrove PVR, Butman CA (1994) Animal-sediment relationships revisited: cause versus effects. Oceanogr Mar Biol Annu Rev 32:111-177

Tulkki P (1977) The bottom of the Bothnian Bay, geomorphology and sediments. Merentutkimuslait Julk/Havsforskningsinst Skr 241:1-89

Valente RM, Rhoads DC, Germano JD, Cabelli VJ (1992) Mapping of benthic enrichment patterns in Narragansett Bay, Rhode Island. Estuaries 15:1-17

Vismann B (1991) Physiology of sulphide detoxification in the isopod Saduria (Mesidotea) entomon. Mar Ecol Prog Ser $76: 283-293$

Voipio A (ed) (1981) The Baltic Sea. Elsevier Oceanography Series 30. Elsevier, Amsterdam

Westerberg J (1978) Benthic community structure in the Aland archipelago (N. Baltic) represented by samples of different sizes. Kieler Meeresforsch, Sonderh 4:53-60

Manuscript first received: April 4, 1996

Revised version accepted: July 23, 1996 